Valley. It is most probable, however, that the mountain is underlain at depth by igneous intrusions.

At the close of the Cretaceous period, at the time of the great Laranude or Rocky Mountain uplift, the sea bottom was uplifted into land, as a part of the Mexican Plateau province, and the rocks were wrinkled and oompressed into the marvelous overthrown folds which they now present, having northeast and north-south trends.

This period of folding was that of the whole of the eastern Rocky Mountain region in north-south directions, and the union of the North and South American continents.

During the later epoch, probably the Miocene, the region and its limestone rocks underwent another orogenic movement, and was intruded from below by a vast igneous magma from which came dikes and ejecta of volcanic rocks which are now found throughout the region. Accompanying this epoch the whole structural or tectonic trend of the southern continent changed from a northsouth to north $40^{\circ}$ west course, and the north $40^{\circ}$ west faults and folds of this later orogenic revolution were developed across the older north-south folds and faults, resulting in the development of the quaquaversal structure of northern Mexico, and I have seen it at $\mathrm{La}$ Mitra, Villadama and Candela, in the State of Coahuila, the Big and Little San Vincente, mountains crossed by the Rio Grande at Presidio San Vincente; at Guaynopita, Jesus Maria and Santa Rosalia, Mexico; and at Monument Mountain near El Paso, and in the Santragos Chinati and other mountains of Trans-Pews, Texas. The great mineral lodes of Mexico were mostly intruded, as hot vapors, waters and gases up these northwesterly fault zones.

Since or during this secend epoch, the plateau as a whole has been uplifted, increasing the erosion, and the surface has worn down at least 2,000 feet. Some of the mineral contents have been washed away; others have concentrated down the fractures enriching the present ore bodies.

As the writer has previously shown, nearly all of the great ore localities of Mexico are associated with faults in this north $40^{\circ}$ west direction. These faults are all of late geological origin, and probably the movements of the earth which made them are still going on, as testified by hot springs, in the vicinity.

By plotting the trends of the faults and folds of the Cordilleran region upon a large map, such as cannot be produced here, it certainly appears as if the northern part of the Mexican plateau province from the Colorado plateau southward through the northern tier of the States of Mexico has been the site of the crux of two distinct periods of mountain making movements, as illustrated in the Sierra Almoloya. One of these, and the older, has northerly trends representing the Laramide movements of the typical Rocky Mountain type, and the other having the northwestern trends of the Coast Range type, probably representing a post-Miocene revolution. The hypothesis of the crossing of these two belts of deformation explains many of the hitherto unexplained phenomena of our continent along the International Boundary and in Northern Mexico. It is certainly worthy of further test by field observation. Further study may show that the post-Miocene belt of northwest-southeast movement crossing the Laramide or Rocky Mountain north-south movement may extend from California across Mexico and connect with the Antillean movements of the West Indies.

\section{NeW YoRK CITY}

ROBERT T. HILL

THE BIOLOGICAL LABOKATORY OF THE

$$
\begin{aligned}
& U \text {. S. BUREAU OF FISHERIES AT } \\
& \text { WOODS HOLE, MASS. }
\end{aligned}
$$

Investigators and Assistants.-During the past laboratory season, thirty-two investigators were engaged in the study of various phases of marine biology, this number being somewhat larger than has been recorded for any summer within the last four years. Of these investigators, fourteen received a salary from the bureau, while eighteen are to be classed as volunteers. Thirteen junior assistants were also employed for various duties in the laboratory and in the field, two of whom, from the nature of part of their work, have like-

${ }^{1}$ Report of the work for the summer of 1906. 
wise been included among the paid investigators. If we add to the foregoing, a librarian and $a$ clerk, detailed from the Washington office, a collector, permanently employed at the Woods Hole Station, two temporary janitors and a chambermaid, we have fortynine persons directly or indirectly engaged in the furtherance of scientific research. But the list would be quite incomplete without mention of the crews of the vessels Fish Hawk, Phalarope and Blue Wing, who of course rendered assistance of a most important kind.

Collecting.-The purchase of almost an entire new fish trap or pound was necessary at the commencement of the season. This was set, as usual, in Buzzards Bay, at a point not far from Woods Hole, and furnished much of the material used by those engaged in the study of fishes and their parasites. Visits were made from time to time to the extensive group of traps at Menemsha Bight, Marthas Vineyard, where material of value was obtained from the fishermen, who have always gladly cooperated with employes of the bureau in obtaining specimens of interest. Frequent trips were likewise made by the collecting vessels to various parts of Buzzards Bay and Vineyard Sound, and occasionally to more distant points. An unusually large amount of drifting Sargassum from the Gulf Stream was taken in Vineyard Sound, yielding abundant specimens of the extraordinary fishes, mollusks and crustaceans peculiar to the so-called 'gulf weed.' Finally, systematic shore collecting was carried on at various points, furnishing much material for rèsearch purposes as well as records for the biological survey.

Biological Survey.-Definite steps were taken toward bringing this project to a provisional close. No new areas of sea bottom were explored, though dredging was carried on at various points by the Fish Hawk for the purpose of verification and supplementation, and for the collection of bottom deposits. Theso last were submitted to Professor Gilbert van Ingen, of Princeton University, who has undertaken a study of the inorganic constituents of the local sea-floor. This, it is believed, may be of considerable importance in relation to the distribution of the bottom fauna and flora.

There remained considerable unidentified material among the collections of the preceding year, and these were sent to various taxonomic specialists, generally those who had previously done this work. It was found impossible, however, thus to dispose of two groups of great importance numerically, viz., the bryozoa and the amphipods. Accordingly, Dr. R. C. Osburn, of New York City, has undertaken the difficult task of reporting upon the former group; while Dr. Leon J. Cole, of Kingston, R. I., has assumed the equally burdensome task of identifying the amphipods. This latter undertaking is rendered peculiarly thankless, by the recent appearance of a fine monograph on the local amphipods by Professor S. J. Holmes. ${ }^{1}$ The determination of our local bryozoa, on the other hand, may be almost regarded as pioneer work. The labors of Messrs. Osburn and Cole have been continued into the present winter, but it is planned that the lists shall be ready in time to allow of their inclusion in the projected report.

As above mentioned, systematic littoral collecting was conducted in a number of different places, along the shores of both Buzzards Bay and Vineyard Sound. It was not the object to keep thorough-going records of all species taken in each locality, as had been done in the case of the dredging stations. But it was thought desirable to extend the known distribution of certain species, for which few exact records are extant. It is to be hoped that ultimately the distribution of the littoral fauna of this region will be plotted out with the same minuteness as has been done for the bottom forms. The shore collecting was under the direct supervision of Messrs. Cole, Osburn and Sumner. The material collected has been sorted out and has been forwarded (or awaits forwarding) to various authorities. Dr. W. G. Van Name, of Springfield, Mass., has already reported upon the compound ascidians taken during

1'The Amphipods of Southern New England,' Bulletin U. S. Bureau of Fisheries for 1904 (published in 1905), Vol. XXIV., pp. 457-529. 
the past summer, as well as those of the two preceding summers. The other groups have been (or will be) referred to the authorities who have disposed of the dredging material of previous years; and reports are hoped for in time to be incorporated into the published report of the survey.

It is appropriate that mention should here be made of the loss sustained by the bureau in the death of Lieut. Franklin Swift, U.S.N., for two years commanding officer of the Fish Hawk, who died of typhoid fever at Charleston, S. C., on the tenth of November, 1906. Capt. Swift's knowledge of triangulation methods, derived from past experience in the Coast and Geodetic Survey, and from the recent work of the Albatross in Monterey Bay, made him an expert in that particular branch of navigation required in systematic dredging operations. The conscientious accuracy - of his methods was felt by all of those who witnessed his work at Woods Hole.

Report upon the Work accomplished.-It has been thought desirable to bring the present biological survey to a provisional close, and to publish the results of the work already accomplished. With this in view, the present writer, who has directed the scientific work at the Woods Hole station for the past four summers, has been employed by the bureau to complete these results during the current winter; and a year's leave of absence from college teaching has been granted him for this purpose. A clerk has been detailed, and a scientific assistant appointed, in order to facilitate this undertaking. The work is now being carried out at Woods Hole.

Museum.-The formation of a representative collection of local marine animals was commenced many years ago, though the necessity for such a collection has not always received adequate recognition, and the existing specimens have suffered much from lack of attention. Dr. R. C. Osburn, as acting curator, has recently accomplished much in the way of reorganizing the local museum, and the extensive collecting operations of the past few years have provided much material. The museum now contains a fairly representative set of specimens which have been authorita- tively identified by the various experts assisting in the determination of dredging material. It has been decided to fit up two large rooms upon the third floor of the laboratory building for the reception of these specimens. It is planned to make this a reference collection of local forms of life, rather than a public display of curiosities. Any one who has felt the need of identifying an unfamiliar species in the course of his biological investigations will realize the utility of such a museum.

Library.-The library has always proved to be an extremely important adjunct to this laboratory; and its use has not been restricted to investigators here, but has been extended to the whole scientific colony at Woods Hole. The contents of the library have been in part permanent, in part temporary. The permanent collection consists for the most part of government reports, and of separates donated by various authors. In addition to these, however, an extensive collection of standard biological works and periodicals have for a number of seasons past been loaned by the department of anatomy of Brown University. While greatly appreciating the privilege of using these books, it is felt by the Bureau of Fisheries that the Woods Hole laboratory should possess a permanent and fairly adequate working library of its own. It is the bureau's intention, therefore, to begin the purchase of the more necessary works as soon as funds are available for the purpose.

Individual Investigations.-Of the thirtytwo investigators, nine represented Harvard University; four, Columbia; three each came from Yale University and the College of the City of New York, and two from Brown. The remainder represented thirteen different institutions in the east, west, north and south.

For the purposes of the present synopsis, the

${ }^{2}$ In this computation each investigator has been accredited to the institution in which he had taught or studied during the preceding academic year. Two investigators have been referred to two institutions each. In the ensuing list, on the other hand, that institution has been named to which each investigator went at the close of the summer. 
subjects of research may be rather arbitrarily classified as follows:

General physiology, reactions to stimuli and behavior ................... 11

Taxonomy $\ldots \ldots \ldots \ldots \ldots \ldots \ldots \ldots \ldots \ldots$

Faunal distribution (including survey work) 6

Anatomy and histology ............. 4

Regeneration ................. 3

Embryology (including maturation of the egg) 3

Parasites of fishes .................. 2

Economic, in narrower sense (not including

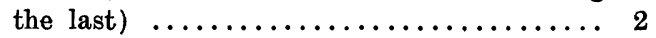

Miscellaneous .................. 5

Total $\ldots \ldots \ldots \ldots \ldots \ldots \ldots \ldots \ldots \ldots \overline{43}$

It must here be borne in mind that some investigators were concerned with more than one subject of research; likewise that in a few instances one subject of research has been included under two heads.

Mention may be appropriately made here of the visit of Sir Frederick Nicholson, of Madras, who was engaged in an investigation of American fisheries methods on behalf of the government of India, and who was the guest of the laboratory for several days.

\section{List of Investigators}

Carl L. Alsberg, A.M., M.D., instructor in biological chemistry, Harvard Medical School: The chemical composition of the blood of selachians.

Arthur M. Banta, A.M., Austin research fellow, Harvard University: The reactions of marine amphipods to light.

Robert P. Bigelow, Ph.D., instructor in biology, Massachusetts Institute of Technology: The Stomatopoda collected by the Albatross.

Wesley R. Coe, Ph.D., assistant professor of comparative anatomy, Yale University: Regeneration in nemerteans.

Leon J. Cole, Ph.D., chief of division of animal breeding and pathology, Agricultural Experiment Station, Kingston, R. I.: Collecting on behalf of biological survey; identification of local amphipods. (Salaried research assistant.)

Edgar D. Congdon, A.M., Austin teaching fellow of Harvard University : Pigment migration in the eyes of crustacea.
Joseph A. Cushman, assistant curator, Boston Society of Natural History: Systematic work upon local sponges, ostracods and foraminifera. (Salaried research assistant.)

Irving A. Field, professor of biology, Westminster College, Westminster, Md.: The food value of some hitherto unused or little used marine animals. (Salaried research assistant.)

Addison Gulick, A.M., graduate student in Harvard University: The histology and function of the osphradium in molluscs.

Chas. W. Hargitt, professor of zoology, Syracuse University: The anthozoa of the Woods Hole region. (Salaried research assistant.)

Geo. T. Hargitt, A.M., teacher of zoology, Syracuse High School, Syracuse, N. Y.: The effect of salt solutions upon regeneration and growth.

Davenport Hooker, student in Yale University, assisted Dr. W. R. Coe.

H. E. Jordan, A.M., fellow in zoology, Princeton University: Cytological studies of echinoderm eggs.

William E. Kellicott, Ph.D., professor of biology, Woman's College, Baltimore: Correlation of external and internal characters in certain fishes.

Beverly W. Kunkel, Ph.D., instructor in biology, Sheffield Scientific School, Yale University: Studies of amphipods and of teleost brains.

Edwin Linton, Ph.D., professor of biology, Washington and Jefferson College, Washington, Pa.: The entozoa of fishes. (Salaried research assistant.)

Jesse F. McClendon, Ph.D., RandolphMacon College, Ashland, Va.: The development of parasitic copepods. (Salaried research assistant.)

Hanford McCurdy, A.M., Cleveland, Ohio: Hybridization experiments with echinoderms.

Charles V. Morrill, graduate student, Columbia University, assisted in the work of the biological survey; likewise was engaged in the study of regeneration in fishes. (Salaried assistant.)

Max Morse, tutor in natural history, Col- 
lege of the City of New York, assisted in the work of the biological survey; likewise carried on studies upon the reactions of Gonionemus. (Salaried assistant.)

Edward Mueller, assistant in American Museum of Natural History, New York: Studies of Hydroids and sea-anemones.

R. C. Mullenix, graduate student, Harvard University: The caudal spinal nerves of elasmobranchs.

Raymond C. Osburn, Ph.D., teacher of zoology in the New York High School of Commerce: Collecting on behalf of the biological survey; identification of local bryozoa. (Salaried research assistant.)

George H. Parker, Ph.D., professor of zoology, Harvard University: The hearing of the weakfish, Cynoscion regalis. (Salaried research assistant.)

Herbert R. Sass, M.A., acting assistant in biology, College of Charleston: Factors influencing the distribution of littoral fauna.

George G. Scott, M.A., instructor in natural history; College of the City of New York: Experiments upon the regeneration of the fins of fishes; experiments upon the physiology of the blood of fishes. (Salaried assistant.)

H. D. Senior, M.B., associate in anatomy, Wistar Institute of Anatomy: The development of the blood vascular system of the teleosts.

Michael X. Sullivan, Ph.D., instructor in physiological chemistry, Brown University: The physiology of the digestive tract of elasmobranchs; the rectal gland of elasmobranchs; experiments to determine the effect of coal-tar contamination upon the health of fishes. (Salaried research assistant.)

Francis B. Sumner, Ph.D., director of the laboratory: Biological survey of local waters; the effects upon fishes of variations in the chemical and osmotic properties of the water.

Millett T. Thompson, Ph.D., assistant professor of zoology, Clark University: The masking habit and the food of the spider crabs.

Lloyd P. Upton, graduate student, Brown University: Physiology of nerve and muscle in the dogfish.

Gilbert van Ingen, $\mathrm{Ph} . \mathrm{D}$., assistant professor of geology, Princeton University: Examination of bottom deposits. (Salaried research assistant.)

Francis B. Sumner

Fisheries Laboratory, Woods Hole, December 15, 1906

\section{AMERICAN ASSOCIATION OF MUSEOMS}

THE second annual meeting of the American Association of Museums will be held in Pittsburg, June 4-6. The headquarters of the association will be at the Hotel Schenley. The first session will be held in the Carnegie Museum on Tuesday, June 4, at ten o'clock. A preliminary program will be issued about May 20. Titles of papers to be presented before the association should be sent as early as possible to Dr. W. J. Holland, Carnegie Museum, Pittsburg. All those interested in the objects of the association are invited to become members and to be present at the meeting. Fees for dues (two dollars for active members, ten dollars for sustaining members) may be sent direct to the treasurer, Dr. W. P. Wilson, the Philadelphia Museums, Philadelphia.

George A. Dorsey, Secretary

\section{THE SMITHSONIAN INSTITUTION AND THE NATIONAL ACADEMY OF SCIENCES AND THE AMERICAN ASSOCIATION FOR THE ADVANCEMENT OF SCIENCE}

IN order to bring in closer touch the representative national scientific organizations of the country and the Smithsonian Institution' at Washington, and to create a new channel for the diffusion of knowledge, Secretary Charles D. Walcott recently extended to the National Academy of Sciences and to the American Association for the Advancement of Science an invitation to make the Smithsonian Institution their headquarters.

The members of the National Academy of Sciences, Secretary Walcott invited "to deposit their archives, records, etc., in rooms provided for the purpose in the Smithsonian Institution, where the secretary of the academy could have access to them and attend to such business as might be necessary 